\title{
RISIKO CEDERA MATA PADA PEKERJA INDUSTRI PIPA BAJA
}

\author{
Arnold MT. Bakara ${ }^{1 *}$, Mei Ahyanti ${ }^{2}$, Prayudhy Yushananta ${ }^{3}$ \\ 1,2,3 Department of Environmental Health, Poltekkes Kemenkes Tanjungkarang.
}

\section{Artikel Info :}

Received 4 Agustus 2020

Accepted 16 Agustus 2020

Available online 24 Agustus 2020

Editor: Ahmad Fikri

Key word :

Safety, Accident, PPE, Knowledge

\section{Kata Kunci :}

K3, Cedera Mata, APD, Pengetahuan

\begin{abstract}
A bstract
An eye injury is a trauma to the eye that can result in damage to the eyeball, eyelids, eye nerves and orbital cavity. Eye injuries can occur due to work processes in various industries, especially in the metal industry. PT. Bakrie Pipe Industry (BPI) is a metal industry that produces steel pipes by changing steel plate sheets into pipe shapes. One of the risks of work accidents in the production process is eye injury due to exposure to particles/gram of iron during the cutting process. This study aims to determine the risk factors for eye injury in workers in the Production Department of PT. Bakrie Pipe Industries, Bekasi, West Java. This study used a cross sectional design involving all workers in the Production Department as research subjects, as many as 36 people. Data collection was carried out by interview and observation, then the data were analyzed using the chi-square test. The risk factors assessed were age, knowledge, attitude, noise and personal protective equipment against eye injury. The results showed that the risk factors for eye injury were knowledge $(O R=$ 280.00; $\quad p$-value $=0,000)$, age $(O R=61.75 ; p$-value $=0,000)$, noise $(O R=39.00 ; p$ value $=0,000)$, and the use of PPE $(O R=17.00 ; p$-value $=0.001)$. Increasing workers' knowledge about work risks is an effort that must be continuously carried out to avoid eye injuries, in addition to the necessity of using Personal Protective Equipment (PPE), and to carry out more intensive supervision.
\end{abstract}

Cedera mata merupakan trauma pada mata yang dapat mengakibatkan kerusakan bola mata, kelopak mata, saraf mata dan rongga orbita. Cedera mata dapat terjadi akibat proses kerja di berbagai industry, terutama pada industri logam. PT. Bakrie Pipe Indusries (BPI) merupakan industri logam yang memproduksi pipa baja dengan cara merubah lembaran plat baja menjadi bentuk pipa. Salah satu risiko kecelakaan kerja pada proses produksi adalah cedera mata akibat terkena partikel/gram besi pada proses pemotongan (cutting). Penelitian bertujuan untuk mengetahui faktor risiko cedera mata pada pekerja di Departemen Produksi PT. Bakrie Pipe Industries, Bekasi, Jawa Barat. Penelitian menggunakan rancangan cross sectional dengan melibatkan seluruh pekerja di Departemen Produksi sebagai subyek penelitian, sebanyak 36 orang. Pengumpulan data dilakukan dengan wawancara dan pengamatan, selanjutnya data dianalisa menggunakan uji chi square. Faktor risiko yang dinilai adalah usia, pengetahuan, sikap, kebisingan dan alat pelindung diri terhadap cedera mata. Hasil penelitian menunjukkan bahwa faktor risiko cidera mata adalah pengetahuan $(O R=280,00 ; p$-value $=0,000)$, usia $(O R=61,75 ; p$ value $=0,000)$, kebisingan $(O R=39,00 ; p$ value $=0,000)$, dan penggunaan $A P D(O R=17,00$; $p$-value $=0,001$. Meningkatkan pengetahuan pekerja tentang risiko kerja merupakan upaya yang harus terus-menerus dilakukan untuk menghindari terjadinya cidera mata, selain keharusan penggunaan Alat Pelindung Diri (APD), dan melakukan pengawasan yang lebih intensif.

\footnotetext{
* Corresponding author: Arnold MT. Bakara

Jl. Soekarno-Hatta No 6, Bandar Lampung, Provinsi Lampung

Email : arnoldbkra@gmail.com
} 


\section{PENDAHULUAN}

Keberadaan pabrik merupakan kunci penentu kemampuan daya saing perusahaan dalam sebuah industri. Pabrik menterjemahkan kebutuhan manajemen agar dapat menjawab permintaan pasar. Dalam kegiatannya, alat kerja, bahan kerja, proses maupun lingkungan kerja dapat mengancam keselamatan kerja. Setiap tahun, ribuan kecelakaan kerja terjadi di tempat kerja yang menimbulkan korban jiwa, kerusakan materi dan gangguan produksi.

Kegiatan proses produksi dapat menyebabkan potensi risiko kecelakaan kerja. Di Indonesia, selama tahun 2012 telah terjadi kecelakaan kerja sebanyak 103.000 kasus. Pada tahun 2013 meningkat menjadi 129.111 kasus atau naik sebesar $11,24 \%$. Hingga akhir tahun 2015, telah terjadi kecelakaan kerja sebanyak 105.182 kasus. Kasus kecelakaan sebagian besar terjadi pada saat bekerja dengan proporsi 69,59\%.(BPJS, 2016).

Secara umum, masalah keselamatan dan kesehatan kerja (K3) di Indonesia masih sering terabaikan, sehingga risiko kecelakaan kerja pada pekerjaan tidak bisa dihindari. Kecelakaan bukan terjadi secara kebetulan, tetapi akibat kurangnya koordinasi pada saat pelaksanaan pekerjaan (Nursyachbani \& Susanto, 2018; Sakinah, 2018). Menurut World Economic Forum, angka kematian akibat kecelakaan kerja di Indonesia pada tahun 2006 mencapai 17-18 untuk setiap 100.000 pekerja (Kani et al., 2013).

PT. Bakrie Pipe Indusries (BPI) merupakan industri logam dengan produksi utama berupa pipa baja. Perusahaan ini didirikan sejak tahun 1959, dan didukung dengan teknologi mesin yang modern, pengelolaan yang efektif dan efisien, serta sumber daya manusia yang inovatif, sehingga berhasil memproduksi pipa baja dengan kualitas dunia dan memenuhi standar internasional (PT. Bakrie Pipe Industries, 2017).

Dalam proses kerjanya terdapat berbagai potensi bahaya yang ditimbulkan oleh mesin/peralatan produksi, manusia, lingkungan kerja, serta proses produksi. Salah satu proses produksi yang berpotensi menimbulkan cedera mata adalah pada proses pemotongan dan penghalusan pipa baja. Hasil studi pendahuluan yang dilakukan pada tanggal 2 Mei hingga 31 Mei 2018, diketahui telah terjadi kecelakaan kerja pada bagian pemotongan pipa yang berakibat pada cidera mata. Kecelakaan oleh paparan partikel atau gram besi saat pemotongan (cutting). Penelitian bertujuan untuk mengetahui faktor risiko cedera mata pada Departement Produksi di PT. BPI.

\section{METODE}

Penelitian merupakan studi evaluasi dengan menggunakan pendekatan kuantitatif yang ditujukan untuk mendapatkan informasi mengenai risiko keselamatan pekerja pada bagian produksi PT. BPI. Penelitian menggunakan rancangan cross sectional dan dilaksanakan pada Bulan Juni hingga Juli 2018, melibatkan seluruh pekerja pada Departemen Produksi sebagai subyek penelitian yang berjumlah 36 orang.

Pengumpulan data dilakukan dengan wawancara dan observasi proses kerja. Data yang terkumpul selanjutnya diolah dan dianalisis menggunakan perangkat lunak SPSS 20.0. Teknik analisis yang digunakan adalah uji Chi square dan Odds Ratio, selanjutnya disajikan dalam bentuk tabel.

\section{HASIL}

PT. BPI menghasilkan berbagai jenis produk pipa baja dengan bahan dasar plat baja. Jenis produk pipa baja yang dihasilkan diantaranya adalah rectangular holow section, steel line pipe ASTM A53 grade, electric resistance welded ste dan beberapa produk lain yang telah memenuhi Standar Nasional Indonesia (SNI). Kegiatan produksi dimulai dari coil storage (tempat penyimpanan coil sebagai bahan baku) hingga finishing plant VAI (proses finishing sesuai standar pipa). Dari kegiatan tersebut, terdapat tahap cut-off pada bagian ini mesin bekerja untuk memotong pipa dengan panjang sesuai order. Alat potong pipa baja tersebut dari meterial HSS yang telah dilakukan machining dan dibuat berbentuk cakram dengan pisau sebanyak 4 buah untuk sekali pasang dengan sistem rotary blade.

Dalam rangkaian pemotongan ini, terjadi potensi risiko terjadinya cedera mata, yang diakibatkan karena pergerakan mata pisau saat memotong pipa dan juga motor listrik yang berfungsi memutar poros drum pada mesin cutoff tersebut. Keluhan yang banyak dirasakan pekerja sebagaimana pada Tabel 1 . 
Keluhan yang paling banyak dirasakan oleh pekerja adalah rasa ada benda asing seperti pasir di mata, mata terasa perih dan bengkak. Sebagian pekerja merasakan air mata keluar dan rasa seperti terbakar pada daerah mata.

Tabel 1. Keluhan yang dirasakan pekerja

\begin{tabular}{ll}
\hline Keluhan & Jumlah \\
\hline Rasa ada benda asing (seperti pasir) & 21 \\
Banyak mengeluarkan air mata & 17 \\
Rasa silau (photophobia) & 12 \\
Terasa perih & 20 \\
Terasa terbakar & 16 \\
Mata bengkak & 19 \\
Penglihatan kabur & 17 \\
\hline
\end{tabular}

\section{Usia}

Usia dikatagorikan dalam kelompok berisiko (17- 29 tahun) dan kelompok tidak berisiko (> 29 tahun). Pada kelompok usia berisiko, terdapat $90,5 \%$ yang mengalami cedera mata, dan 9,5\% tidak mengalami cedera mata. Sedangkan pada kelompok tidak berisiko, terdapat 13,3\% mengalami cedera dan $86,7 \%$ tidak mengalami cedera (Tabel 2).

Hasil uji statistik diperoleh $p$-value $=0,000$ dan $O R=61,75$, menunjukkan hubungan yang bermakna antara usia dan cedera mata. Pekerja dengan usia berisiko berpeluang mengalami cedera mata sebesar 61,750 kali dibadingkan dengan pekerja dengan usia tidak berisiko.

\section{Pengetahuan}

Pada Tabel 2 terlihat bahwa sebanyak 95,2\% pekerja dengan pengetahuan kurang baik mengalami cedera mata. Sedangkan pada kelompok pekerja dengan pengetahuan baik, hanya $6,7 \%$ yang mengalami cedera mata.

Hasil analisa statistik memperoleh $p$-value $=$ 0,000 dan $\mathrm{OR}=280,00$, menunjukkan hubungan yang sangat bermakna antara pengetahuan pekerja dengan kejadian cedera mata. Pekerja berpengetahuan kurang baik berisiko mengalami cedera sebanyak 280,00 kali dibanding pekerja berpengetahuan baik.

\section{Sikap}

Sebanyak $65,2 \%$ pekerja yang memiliki sikap kurang baik mengalami cedera mata. Hasil uji statistik meyatakan hubungan yang tidak bermakna antara sikap dengan terjadinya cedera mata pada pekerja (Tabel 2).

\section{Penggunaan APD}

APD merupakan alat yang dapat melindungi keselamatan pekerja dari bahaya yang diakibatkan dari pekerjaan. Hubungan antara penggunaan APD dengan kejadian cedera mata dapat dilihat pada Tabel 2 .

Pada kelompok pekerja dengan penggunaan APD kurang baik, sebanyak $85 \%$ mengalami cedera mata dan $15 \%$ tidak mengalami cedera mata, sedangkan pada kelompok pekerja dengan penggunaan APD yang baik, hanya $25 \%$ yang mengalami cedera mata dan $75 \%$ tidak mengalami cedera mata. Diperoleh $p$-value = 0,000 dan $O R=17,00$, menunjukkan hubungan yang sangat bermakna antara penggunaan APD dengan kejadian cedera mata. Pekerja dengan penggunaan APD kurang baik berisiko mengalami cedera sebanyak 17,00 kali dibanding pekerja dengan penggunaan APD yang baik.

\section{Kebisingan}

Kebisingan dapat menjadi hal yang mengganggu dalam pelaksanaan pekerjaan. Demikian halnya dengan kejadian cedera mata pada pekerja produksi pipa baja. Hubungan antara kebisingan dengan cedera mata pada pekerja dapat digambarkan pada Tabel 2.

Dari hasil analisis hubungan kebisingan dengan cedera mata dapat diperoleh $p$-value = 0,000, maka disimpulkan bahwa terdapat hubungan yang bermakna antara bisingan dengan kejadian cedera mata. Pekerja dengan penggunaan APD kurang baik berisiko mengalami cedera sebanyak 39,00 kali dibanding pekerja dengan penggunaan APD yang baik.

\section{PEMBAHASAN}

Hasil analisa bivariat menunjukkan usia risiko untuk mengalami cedera mata adalah pada usia 17-29 tahun. Hasil ini sejalan dengan yang disampaikan oleh Sukamto (2014) dalam (Aryatiningsih \& Husmaryuli, 2016) bahwa kecelakaan kerja umumnya paling sering terjadi pada usia antara 17 - 29 tahun, kemudian akan turun sesudah mencapai titik terendah pada usia $\geq 30$ tahun. 
Banyaknya kasus kecelakaan kerja diakibatkan oleh perilaku yang sembrono, kurangnya pengalaman, senang mencoba-coba. Perilaku tidak aman ini membahayakan diri pekerja sendiri. Sebaiknya perusahaan lebih selektif memilih tenaga kerja dilihat dari faktor usia mengingat kedewasaan seseorang akan mempengaruhi tindakan dan perilaku aman. Dengan demikian pekerja dapat terhindar dari kecelakaan kerja (Insanno, 2016).

Tabel 2. Hubungan Pengetahuan dengan Cedera Mata pada Pekerja PT. BPI

\begin{tabular}{|c|c|c|c|c|c|c|c|}
\hline \multirow{2}{*}{ Variabel } & & \multicolumn{2}{|c|}{ Cidera } & \multicolumn{2}{|c|}{ Tidak Cidera } & \multirow{2}{*}{$\mathrm{p}$-Value } & \multirow{2}{*}{$\begin{array}{l}\text { OR } \\
95 \% \mathrm{Cl}\end{array}$} \\
\hline & & $\mathrm{n}$ & $\%$ & $\mathrm{n}$ & $\%$ & & \\
\hline \multirow{2}{*}{ Usia } & 17-29 tahun & 19 & 90,5 & 2 & 9,5 & \multirow{2}{*}{0,000} & 61,75 \\
\hline & $>29$ tahun & 2 & 13,3 & 13 & 86,7 & & $(7,69-495,79)$ \\
\hline \multirow{2}{*}{ Pengetahuan } & Kurang Baik & 20 & 95,2 & 1 & 4,8 & \multirow{2}{*}{0,000} & 280,00 \\
\hline & Baik & 1 & 6,7 & 14 & 93,3 & & $(16,12-4863,44)$ \\
\hline \multirow{2}{*}{ Sikap } & Kurang Baik & 15 & 65,2 & 8 & 34,8 & \multirow{2}{*}{0,581} & 2,188 \\
\hline & Baik & 6 & 46,2 & 7 & 53,8 & & $(0,54-8,76)$ \\
\hline \multirow{2}{*}{ APD } & Kurang Baik & 17 & 85,0 & 3 & 15,0 & \multirow{2}{*}{0,000} & 17,00 \\
\hline & Baik & 4 & 25,0 & 12 & 75,0 & & $(3,20-90,24)$ \\
\hline \multirow{2}{*}{ Kebisingan } & Kurang Baik & 18 & 90,0 & 2 & 10,0 & \multirow{2}{*}{0,000} & 39,00 \\
\hline & Baik & 3 & 18,8 & 13 & 81,2 & & $(5,68-267,66)$ \\
\hline
\end{tabular}

Telah dijelaskan bahwa pada kelompok pekerja dengan pengetahuan kurang baik, ada 95,2\% mengalami cedera mata dan $4,8 \%$ tidak mengalami cedera mata, sedangkan pada kelompok pekerja dengan pengetahuan baik, hanya $6,7 \%$ yang mengalami cedera mata dan 93,3\% tidak mengalami cedera mata. Diperoleh $p$-value $=0,000$ dan OR $=280$, dapat diartikan terdapat hubungan yang bermakna antara pengetahuan pekerja dengan kejadian cedera mata. Pekerja berpengetahuan kurang baik berisiko mengalami cedera sebanyak 280 kali dibanding pekerja berpengetahuan baik.

Kecelakaan kerja berkaitan erat dengan pengetahuan pekerja tentang bahaya (Mufarokhah, 2006). Pengetahuan yang baik akan membuat pekerja melakukan tindakan aman terhadap dirinya (Amelia, 2019; Hasanah et al., 2012; Indrayani, 2017; Yudhawan \& Dwiyanti, 2017).

Pekerja yang memiliki pengetahuan baik, akan mampu membedakan dan mengetahui adanya bahaya di lingkungan sekitar serta dapat melakukan upaya pencegahan sesuai dengan prosedur yang ada. Mereka sadar akan risiko yang diterima, sehingga kecelakaan kerja dapat dihindari. Pekerja akan cenderung menghindari kecelakaan ringan, karena kecelakaan ringan akan menyebabkan kecelakaan kerja yang lebih besar dan parah. Pekerja dengan pengetahuan baik bertindak positif supaya terhindar dari kecelakaan kerja.

Sebaliknya, pekerja yang memiliki pengetahuan kurang tentang prosedur kerja dan peraturan dalam melindungi pekerja, akan cenderung bekerja terburu-buru dan ingin cepat selesai, sehingga seringkali faktor keselamatan terabaikan. demi menghemat waktu dan memperoleh waktu istirahat yang lebih lama. Oleh karena itu pengetahuan yang rendah akan keselamatan dan kesehatan kerja dapat menimbulkan kecelakaan ringan maupun yang lebih parah.

Pekerja sebaiknya memiliki pengetahuan yang baik tentang keselamatan dan kesehatan kerja agar dapat mengidentifikasi bahayabahaya yang ada di sekitar lingkungan kerja yang mengancam dirinya. Tujuan dari identifikasi bahaya adalah penilaian risiko dengan memperkirakan tingkat keparahan yang akan timbul jika pekerja mendapatkan kecelakaan kerja. Ketika risiko telah teridentifikasi, dianalisis dan dinilai, pekerja dapat membuat keputusan tentang tindakan pencegahan. Dengan demikian responden dapat menghindari terjadinya kecelakaan kerja ataupun mengurangi tingkat keparahan yang timbul.

Beberapa penelitian memperlihatkan hubungan yang kuat antara sikap dan kecelakaan kerja. Namun, pada penelitian ini 
tidak ditemukan hubungan yang signifikans antara sikap dengan tejadinya kecelakaan kerja. Lebih dari separuh pekerja $(65,2 \%)$ menunjukkan sikap yang baik. Banyak penelitian yang menyimpulkan adanya hubungan yang sangat lemah bahkan negatif, sedangkan sebagian lain menemukan adanya hubungan yang meyakinkan (Azwar, 2011).

Pembentukan sikap dapat dipengaruhi oleh pengalaman pribadi, pengaruh orang lain yang dianggap penting, pengaruh kebudayaan dan media informasi. Oleh karena itu upaya yang dapat dilakukan perusahaan guna mengurangi kecelakaan adalah membuat permodelan dengan menghadirkan beberapa pekerja yang berprestasi yang patut ditiru oleh pekerja lain. Dengan adanya permodelan ini diharapkan dapat mempengaruhi sikap positif dari pekerja. Selain itu melaksanakan safety talk dan penyuluhan keselamatan kerja sebagai salah satu media informasi bagi pekerja.

Pada kelompok pekerja dengan penggunaan APD kurang baik, ada $85 \%$ mengalami cedera mata dan $15 \%$ tidak mengalami cedera mata, sedangkan pada kelompok pekerja dengan penggunaan APD yang baik, hanya $25 \%$ yang mengalami cedera mata dan $75 \%$ tidak mengalami cedera mata. Diperoleh $p$-value $=$ 0,000 dan $O R=17,000$, dapat diartikan terdapat hubungan yang bermakna antara penggunaan APD dengan kejadian cedera mata. Pekerja dengan penggunaan APD kurang baik berisiko mengalami cedera sebanyak 17 kali dibanding pekerja dengan penggunaan APD yang baik.

Kedisiplinan pekerja menggunakan APD berhubungan sangat erat dengan terjadinya kecelakaan kerja (Nayaka et al., 2014). Demikian pula Alfanan (2014), ada pengaruh yang signifikan antara pemakaian APD mata terhadap ketajaman penglihatan pegawai bengkel las. Pemakaian APD mata merupakan faktor yang mempengaruhi ketajaman penglihatan pegawai bengkel las (Alfanan, 2014). Pekerja yang tidak menggunakan APD lebih sering mengalami gangguan penglihatan mata, pernafasan maupun kulit (Asrini, 2013).

Banyaknya pekerja yang tidak menggunakan APD disebabkan karena pengetahuan yang kurang dan sikap kurang setuju terhadap penggunaan APD dengan alasan mengganggu kerja (tidak nyaman). APD buan satu-satunya sarana untuk menghindari kecelakaan kerja. Tetapi penggunaan APD dapat meminimalisir jumlah kontak dengan bahaya dengan menempatkan penghalang anatar pekerja dengan bahaya, sebagai upaya terakhir dalam usaha melindungi tenaga kerja.

Proses cutting diawali dengan merancang pola atau membuat garis pada bahan yang diperlukan kemudian selanjutnya dilakukan cutting terhadap bahan tersebut. Pada proses ini menggunakan alat pemotong yang digerakkan oleh operator. Dari proses pemotongan ini, seringkali ada serpihan yang terlempar kearah pekerja, sehingga pekerja harus menggunakan APD untuk menghindari adanya kecelakaan kerja. APD yang wajib digunakan di area ini adalah, helm pengaman, sepatu pelindung, masker, kacamata pelindung, alat pelindung telinga dan sarung tangan (Sakinah, 2018).

Alat pelindung diri mata harus nyaman digunakan, tidak mengganggu kerja dan memberikan perlindungan terhadap pekerja dari Kecelakaan Akibat Kerja (KAK) dan Penyakit Akibat Kerja (PAK). Selanjutnya, yang harus dilakukan perusahaan adalah penerapan penggunaan APD dan pengawasan terhadap pekerja.

Penjelasan yang dapat disajikan berdasarkan tabel 4 adalah terdapat hubungan yang bermakna antara bisingan dengan kejadian cedera mata. Pekerja dengan penggunaan APD kurang baik berisiko mengalami cedera sebanyak 39 kali dibanding pekerja dengan penggunaan APD yang baik.

Hasil ini diperkuat oleh penelitian Ulandari et al., (2014) yang menyatakan bahwa gangguan fisiologis, psikologis dan komunikasi menyebabkan terganggunya pekerja, bahkan mungkin mengakibatkan kesalahan atau kecelakaan, terutama pada penggunaan tenaga kerja baru oleh karena timbulnya salah paham dan salah pengertian.

Kebisingan dapat mengganggu kegiatan sehari-hari seperti konsentrasi dan menyebabkan pengalihan perhatian sehingga tidak fokus kepada pekerjaan yang sedang dihadapi. Terganggunya pelaksanaan dan pencapaian hasil kerja oleh kebisingan dapat dikarenakan adanya perasaan terganggu dan melemahnya semangat kerja atau masalah 
lainnya seperti kurang istirahat, terganggunya sistem pencernaan, sistem saraf dan lainnya.

\section{SIMPULAN}

Penelitian mendapatkan bahwa faktor risiko terjadinya cidera mata pada pekerja di bagian produksi PT. Bakrie Pipe Industries adalah usia, pengetahuan, penggunaan APD dan kebisingan. Penting bagi perusahaan untuk meningkatkan pengetahuan pekerja tentang risiko kecelakaan kerja, khususnya cidera mata, serta meningkatkan keterampilan kerja sehingga mengurangi risiko kecelakaan.

Penggunaan APD menjadi suatu keharusan bagi seluruh pekerja dengan disertai pengawasan, bahkan sanksi. Di sisi lain, perusahaan harus menyediakan APD yang mencukupi, pengawasan, serta mengendalikan kualitas lingkungan kerja.

\section{DAFTAR PUSTAKA}

Alfanan, A. (2014). Pengaruh Pemakaian Alat Pelindung Mata Terhadap Ketajaman Penglihatan Pegawai Bengkel Las di Wilayah Terminal Bus Wisata Ngabean Kota Yogyakarta. Jurnal Medika Respati, 9(3), Hal. 1-11.

Amelia, R. (2019). Faktor-Faktor yang menyebabkan Kecelakaan Kerja pada Pekerja Bagian Pengelasan di PT. Johan Santosa. Jurnal Kesehatan Masyarakat, 3(1), Hal. 35-49. https://doi.org/10.1017/CBO9781107415324.00 4

Aryatiningsih, D. S., \& Husmaryuli, D. (2016). Kejadian Kecelakaan Kerja Pekerja Aspal Mixing Plant (AMP) \& Batching Plant di PT. LWP Pekanbaru Tahun 2015. Jurnal Kesehatan Masyarakat Andalas, 10(2), Hal. 145-150. https://doi.org/10.1134/S1028334X07080132

Asrini. (2013). Gambaran Penggunaan Alat Pelindung Diri dan Gangguan Kesehatan Pekerja Industri Meubel di Kecamatan Tolangohula Kabupaten Gorontalo. Jurnal Ilmu Kesehatan Dan Keolahragaan, 1(1), Hal. 1-8.

Azwar, S. (2011). Sikap dan perilaku dalam: sikap manusia teori dan pengukurannya. Pustaka Pelajar.

BPJS. (2016). Jumlah Kecelakaan Kerja Di Indonesia Masih Tinggi.

https://www.bpjsketenagakerjaan.go.id/berita/5 769/Jumlah-kecelakaan-kerja-di-

Indonesiamasih-tinggi.html
Hasanah, P. U., Faisya, A. F., \& Camelia, A. (2012).

Penilaian Risiko Keselamatan Kerja Pada Kegiatan Produksi Lateks Pekat (Konsentrat) Di PT Bumi Rambang Kramajaya Gandus Palembang. Jurnal Ilmu Kesehatan Masyarakat, 3(1), hal. 69-80.

Indrayani, R. (2017). Analisis Risiko Keselamatan Kerja Pada Proyek Pengembangan Bandara Internasional Juanda Terminal 2 Surabaya. Ikesma, 13(2), Hal. 77-93. https://doi.org/10.19184/ikesma.v13i2.7029 Insanno, J. S. (2016). Perbedaan Unsafe Actions Antar Shift Kerja Pada. The Indonesian Journal of Occupational Safety and Health, 2(2), Hal. 132141. http://ejournal.unair.ac.id/index.php/IJOSH/article/view /4180/2825

Kani, B. R., Mandagi, R. J. M., Rantung, J. P., \& Malingkas, G. Y. (2013). Keselamatan dan Kesehatan Kerja Pada Pelaksanaan Proyek Konstruksi (Studi Kasus: Proyek PT. Trakindo Utama). Jurnal Sipil Statik, 1(6), Hal. 430-433. https://doi.org/10.4135/9781848608399.n25

Mufarokhah, L. (2006). Hubungan pengetahuan keselamatan kerja dengan pelaksanaan pencegahan kecelakaan kerja pada karyawan bagian spining di PT. Primatexco Indonesia Batang [Universitas Negeri Semarang]. https://lib.unnes.ac.id/3317/1/1251a.pdf

Nayaka, I. G. M. W. S., Sarjana, I. M., \& Priyanto, I. M. D. (2014). Jaminan Sosial Pekerja Kontrak Pada Hotel Bali Mandira Beach Resort \& SPA. Jurnal Universitas Udayana, 04(03). https://ojs.unud.ac.id/index.php/kerthasemaya/ article/view/20068/13337

Nursyachbani, P. A., \& Susanto, N. (2018). Analisis Risiko Kecelakaan Kerja pada Proyek Underpass Jatinengaleh Semarang dengan Metode Failure Mode and Effect Analysis (FMA). Industrial Engineering Online Journal, 6(4), Hal. 1-7.

PT. Bakrie Pipe Industries. (2017). Company Profil.

Sakinah, Z. V. (2018). Aplikasi Health Belief Model

Dalam Menganalisis Perilaku Penggunaan Kacamata Pelindung. Jurnal PROMKES, 5(1), Hal. 105-115. https://doi.org/10.20473/jpk.v5.i1.2017.115-128

Ulandari, A. A., Naiem, M. F., \& Wahyuni, A. (2014). Hubungan Kebisingan Dengan Keluhan Kesehatan Non Pendengaran Pada Pekerja Instalasi Laundry Rumah Sakit Kota Makassar. Universitas Hasanudin, Makasar. 
Yudhawan, Y. V., \& Dwiyanti, E. (2017).

Hubungan Personal Factors Dengan Unsafe Actions Pada Pekerja Pengelasan Di PT DOK

Dan Perkapalan Surabaya. Jurnal Ilmiah

Kesehatan Media Husada, 6(1), Hal. 141-150.

https://doi.org/10.33475/jikmh.v6i1.70 